\title{
GANGGUAN KEPRIBADIAN ANTISOSIAL PADA NARAPIDANA
}

\author{
Meilanny Budiarti S. ${ }^{1}$, Hetty Krisnani ${ }^{2}$, Gevia Nur Isna Deraputri ${ }^{3}$ \\ meilannybudiarati13@gmail.com; hettykrisnani@yahoo.com;gderaputri@gmail.com;
}

\begin{abstract}
ABSTRAK
Artikel ini membahas mengenai gangguan psikopat atau antisosial yang terjadi pada narapidana. Psikopat merupakan perilaku psikologis yang terjadi pada manusia. Psikopat ini merupakan keadaan seseorang dimana seseorang tersebut tidak dapat merasakan empati dan cenderung untuk dapat melakukan kekerasan pada manusia lain tanpa diikuti dengan perasaan bersalah dan melakukan perilaku tersebut untuk kepuasan dirinya sendiri dan mereka cenderung untuk membenarkan dirinya sendiri atas perbuatan yang dilakukannya. Narapidana adalah seseorang yang hidup dalam tahanan atau sel penjara karena mereka telah melakukan tindakan-tindakan menyimpang yang tidak sesuai dengan norma dan nilai-nilai yang ada pada masyarakat.

Tidak sedikit dari narapidana yang ada didalam sel tahanan yang teridentifikasi mempunyai prilaku psikologis yang menyimpang yaitu psikopat. Mereka, narapidana penyandang psikopat, cenderung tidak memiliki kemampuan untuk mengenali dan belajar dari kesalahan yang mereka lakukan sebelumnya. Beberapa mendefinisikan penyebab dari psikopat ini adalah karena gangguan pada sel otak dan juga pengaruh lingkungan dari orang tersebut yang terbentuk sejak mereka kecil.

Pada artikel ini akan menjelaskan mengenai apa itu psikopat, bagaimana narapidana yang mempunyai gangguan psikopat, dan bagaimana seharusnya penanganan untuk narapidana yang tinggal dan menetap di sel penjara yang mengidap penyakit mental. Serta, bagaimana pekerja sosial dalam kasus ini berperan untuk dapat memanusiakan manusia.
\end{abstract}

Kata kunci : Gangguan Psikopat, Narapidana dengan gangguan psikopat

\section{ABSTRACT}

This article discusses the psychopathic or antisocial disorders that occur on inmates. Psychopaths is a psychological behavior that occurs in humans. Psychopaths disorder is a situation where one person is unable to feel empathy and tends to be violent to other humans without feeling guilty and perform these behaviors for themselves and their satisfaction justifies itself on the act of doing. Inmates are someone living in detention or prison cells because they have committed acts which do not deviate in accordance with the norms and values that exist in society.

Some of the inmates that there were unidentified having antisocial personality disorder. inmates with psychopathic does not have the ability to recognize and learn from the mistakes they did before. but they also can behave either like a normal person and do not show that they have a personality disorder. Some define the cause of the psychopath is due to disturbances in brain cells and also environmental influence of the person who formed since they are small.

This article will explain about what is a psychopath, how prisoners who have psychopathic disorders, and how should the handling of prisoners who live and stay in a prison cell with mental illness. As well, how social workers in this case contribute to humanize humans.

Key words: antisocial personality disorder, inmates with psychopathic disorders

\section{PENDAHULUAN}

Selama ini kita sebagai masyarakat umum mengetahui penjara atau lapas adalah tempat bagi orang-orang yang melanggar hukum, melakukan kejahatan, atau orangorang tersebut telah melanggar aturan dan norma yang telah diatur dan diyakini dalam suatu tatan masyarakat. Mendekap ditahanan dan ada dalam keterasingan adalah sebuah bentuk hukuman atas perbuatan yang mereka lakukan. Penjara dianggap sebagai suatu tempat pengasingan mereka dari masyarakat 
luas agar mereka, orang yang melakukan pelanggaran, dapat menyadari perbuatan mereka, menjadi jera, dan tidak mengulangi pelanggaran hukum yang mereka lakukan sebelumnya. Mereka tinggal didalam sel tahanan sampai dengan waktu yang sudah ditentukan sesuai dengan masa hukuman yang mereka terima.

Bagaimana seseorang mendekap dirumah tahanan diatur melalui prosedur hukum yang berlaku. Mereka yang mendekap didalam sel tahanan biasanya adalah mereka yang melakukan pelanggaran yang dianggap meresahkan masyarakat seperti perampokan, pelecehan, pengedar dan pemakai narkotika, pembunuhan, dan pelangaran-pelanggaran lain dan sudah mendapatkan keputusan dari persidangan sebelum akhirnya mereka dapat mendekap menjadi tahanan.

Bisa kita bayangkan bahwa dalam sebuah penjara terdapat banyak ragam individu yang melakukan pelanggaran dan mereka disatukan dalam sebuah tempat. dari beberapa buku yang saya baca dan juga film, baik fiksi maupun non fiksi, mereka menjelaskan dan menggambarkan bahwa kehidupan penjara merupakan kehidupan yang kejam bagi penghuninya dan tidak jarang juga beberapa berita mengabarkan bahwa kejahatan juga dapat terjadi antar sesama narapidana. Ada hubungan kuat antara kriminalitas dan perilaku psikopat atau antisosial, namun tidak semua kriminalitas menunjukan gejala psikopat dan tidak semua psikopat berperilaku kriminalis (Lilienfeld \& Andrews, 1996).

Dalam beberapa kasus, narapidana yang mendekap di sel tahanan juga dapat mengalami gangguan mental pada dirinya bisa dikarenakan akibat tekanan yang mereka terima dalam sel tahanan atau juga memang narapidana tersebut telah mempunyai masalah pada kesehatan mentalnya. Namun apakah kesehatan mental pada narapidana diperhatikan oleh petugas penjara. Dikutip dari buku Mental Health and Social Problem a Social Work Perspective, Menurut James dan Glaze, 64 persen dari jumlah tahanan yang mendekap di penjara mempunyai masalah kesehatan pada mental mereka. Tidak hanya orang dewasa, kalangan remaja juga mengalami masalah kesehatan pada mental mereka.

Gangguan psikopat merupakan salah satu dari masalah kesehatan mental namun gangguan psikopat tidak seperti gangguan mental yang lainnya yang biasa ditemukan pada manusia seperti depresi, stress, bipolar atau kepribadian ganda dan yang lainnya. Orang yang mengalami gangguan psikopat pada dirinya cenderung tidak teridentifikasi kepribadiannya maka dari itu gangguan psikopat tidak sama dengan gangguan mental yang lainnya. Menurut National Comorbidity Survey (Klassler dkk, 1994) gangguan kepribadian antisosial lima kali lebih umum dijumpai pada laki-laki dibandingkan pada perempuan, meskipun demikian, gangguan tersebut telah tumbuh dengan cepat di antara perempuan di tahun-tahun terakhir ini.

Dalam sebuah studi di Amerika yang mempelajari mengenai narapidana menemukan bahwa lebih dari 20 persen narapidana disebuah penjara menengan setempat merupakan pengidap psikopat dengan tingkat psikopati yang berbeda dari rendah, sedang, hingga tinggi melalui tes otak MRI pada lebih dari 120 narapidana atau napi (sumber: duniafitnes.com).

Salah satu narapidana yang dikenal dengan gangguan psikopat adalah Ted Bundy bernama asli Thedore Robert Cowell, pria yang lahir pada 24 november 1946. Ia disebut sebagai pembunuh berdarah dingin, sangat terkenal di kepolisian Amerika karena telah terbukti membunuh dan menculik 35 wanita, mayoritas perempuan berkulit putih. Korban diperkosa terlebih dahulu sebelum akhirnya dibunuh. Akibat perbuatannya tersebut ia dihukum mati pada tahun 1989. Menurut peng acaranya, John Henry Browne, bahwa 
Ted Bundy mengaku sudah menghabisi lebih dari 100 nyawa orang dan bukan hanya perempuan dan Ted menyadari bahwa benarbenar jahat. Ted sempat berasil kabur dari penjara namun berhasil di tangkap kembali. (sumber bacaan : m.jpnn.com).

Kasus lain orang dengan gangguan psikopat yang melakukan tindakan kriminal adalah Jeffrey Dahmer Lionel, lahir pada tanggal 21 Mei 1960. Ia merupakan pembunuh berantai yang membunuh lakilaki. Pembunuhan tersebut dia lakukan melibatkan pemerkosaan, mutilasi, necrophilia atau berhubungan seks dengan mayat, dan juga kanibalsme. Sekitar setengah dari tahanan yang dapat didiagnosis dengan gangguan kepribadian antisosial (Robins dkk, 1991). Sebaliknya, kurang dari setengah orang dengan gangguan kepribadian antisosial yang melanggar hukum (Robins dkk, 1991).

Bagaimana seorang narapidana, yang notabennya adalah seorang kriminal, dapat terdeteksi apakah mengidap gangguan psikopat atau tidak. Dan bagaimana pekerja sosial yang bekerja didalam penjara dapat memfasilitasi narapidana yang mempunyai gangguan kepribadian antisosial tersebut.

\section{TINJAUAN PUSTAKA}

Agar dapat lebih mendalami mengenai bagaimana narapidana yang mempunyai gangguan kepribadian antisosial yang ada dalam sel tahanan perlu adanya kajian mengenai konsep-konsep yang terkait terlebih dahulu sebelum membahas lebih lanjut mengenai apa yang menjadi fokus dari pembahasan. Adapun dalam bagian ini juga akan dijelaskan mengenai apa itu definisi kesehatan mental, apa itu gangguan kepribadian antisosial atau biasa kita kenal dengan nama gangguan psikopat pada manusia termasuk ciri-cirinya, dan konsepkonsep yang terkait dengan bahasan yang masuk pada bagian pembahasan.

\section{Kesehatan Mental (Mental Health)}

Mental health atau kesehatan mental merupakan kondisi dimana seseorang memiliki jiwa yang sehat, dengan kata lain, dapat berfungsi dengan baik. Definisi kesehatan mental juga diatur dalam undangundang no 3 tahun 1966 dalam pasal 1 (a) pada bagian penjelasan adalah satu kondisi yang memungkinkan perkembangan fisik, intelektuil dan emosionil yang optimal dari seseorang dan perkembangan itu berjalan selaras dengan keadaan orang-orang lain, makna kesehatan jiwa mempunyai sifat-sifat yang harmonis (serasi) dan memperhatikan semua segi-segi dalam penghidupan manusia dan dalam hubungannya dengan manusia lain.

Kesehatan mental merupakan sebuah konsen ilmu yang mempelajari mental dan jiwa dengan objek nya adalah manusia sebagai makhluk yang mempunyai jiwa dan mental. Ada beberapa definisi mengenai kesehatan mental. Alexander Schneuders mengatakan bahwa dalam Semiun (2006:23) "ilmu kesehatan mental adalah ilmu yang mengembangkan dan menerapkan seperangkat prinsip yang praktis dan bertujuan untuk mencapai dan memelihata kesejahteraan psikologis organisme manusia dan mencegah gangguan mental serta ketidakmampuan menyesuaikan diri" (Schneiders, 1965).

Adapun kriteria dari kesehatan mental menurut Alexander Schneiders dalam personality Dynamics and mental health (1965) adalah sebagai berikut :

1) Efisiensi Mental

2) Pengendalian dan Integrasi Pikiran dan Tingkah Laku

3) Integrasi motif-motif serta pengendalian konflik dan frustasi

4) Perasaan-perasaan dan emosi-emosi yang positif dan sehat

5) Ketenangan atau kedamaian pikiran 
6) Sikap-sikap yang sehat

7) Konsep diri yang sehat

8) Identitas ego yang adekuat

9) Hubungan yang adekuat dengan kenyataan.

Alexander (1999) membahas mengenai elemen dengan ketetapan dari pelayanan kesehatan mental untuk penjara dan pertanggungjawaban yang legal untuk pekerja sosial dengan konteks penjara. Alexander mendiskusikan bahwa:

Pekerja sosial harus menjamin tahanan untuk mendapatkan pelayanan profesional paling tidak harus dilakukannya assesment kepada tahanan yang mempunyai masalah kesehatan mental. Untuk tahanan dengan kecenderungan bunuh diri, intervensi yang penting perlu dilakukan. Untuk penyakit mental yang serius pada tahanan, pelayanan harus disertai dengan bantuan profesional untuk mengurangi stres yang terjadi pada tahanan dan menambah fungsi mereka. Saat beberapa tahanan mungkin perlu untuk pengobatan, mengadakan konseling individu dan kelompok dapat menjadi pilihan dan mungkin akan bergina bagi mereka dan yang lainnya.

Pasal 1 angka 7 Undang-undang No. 12 Tahun 1995 tentang Pemasyarakatan (UU12 thn 1995) menjelaskan bahwa narapidana adalah terpidana yang menjalani pidana hilang kemerdekaan di Lembaga Pemasyarakatan ("LAPAS"). Sedangkan, pengertian terpidana sendiri adalah seseorang yang dipidana berdasarkan putusan pengadilan yang telah memperoleh kekuatan hukum tetap (Pasal 1 angka 6 UU 12/1995). Oleh karena itu, selama perkara tersebut masih menempuh proses peradilan dan berbagai upaya hukum selanjutnya, orang tersebut belum dikatakan sebagai narapidana.

\section{Psikopat atau Antisocial Personality Disorder (ASPD)}

Barry dalam bukunya Mental Health and Mental Illness mendefinisikan antisocial personality disorder (ASPD) sebagai salah satu penyakit kepribadian yang berbahaya. Ia menyatakan orang yang mengalami gangguan kepribadian antisosial bahwa :

"they are frequently in trouble with the law, and might first be seen in psychiatric consultation on the recommendation of the court or probation office. They are unable to tolerate frustation, are easily enraged, and can act out violently without feeling remorse. They sometimes describe as cold-blooded and are often described by others as such. They can be ruthless and vindictive and tend to blame others for their behaviour. people with antisocial personality disorder demand much and give little. they are typically affection less, selfish, ungrateful, and self centered, and may be exhibitionistic. they are unable to judge their behaviour from another's standpoint" (Barry 1998:340)

Menurut buku Psikologi Abnormal karya Nevid dkk (2005): "Orang dengan gangguan kepribadian antisosial melakukan pelanggaran terhadap hak-hak orang lain dan sering melanggar hukum”. Mereka mengabaikan norma dan konvesi sosial dan impulsif. Meski demikian mereka biasanya menunjukan karisma dalam penampilan luar mereka dan paling tidak memiliki intelegasi di atas rata-rata orang normal pada umumnya (Cleckley, 1976). Penderita gangguan Psikopat, sosiopat, atau antisosial ini identik dengan perilaku tidak bermoral dan asosial, impulsif serta kurang memiliki penyesalan dan rasa malu. 
Pola perilaku yang menandai gangguan kepribadian antisosial dimulai dari masa kanak-kanak atau remaja dan berlanjut hingga dewasa. Perilaku antisosial dan kriminal yang terkait dengan gangguan ini cenderung menurun sesuai usia, dan mungkin akan menghilang pada saat orang tersebut mencapai umur 40 tahun. Namun, tidak demikian dengan trait kepribadian yang mendasari gangguan antisosial-trait seperti egosentrisitas; manipulatif; kurangnya empati; kurangnya rasa bersalah atau penyesalan; dan kekejaman pada orang lain. Hal-hal tersebut relatif stabil meski terdapat penambahan usia (Herpur \& Hare, 1994)

Faktor-faktor sosiokultural dan gangguan kepribadian antisosial, gangguan ini lebih umum terjadi dalam kelompok sosial ekonomi yang lebih rendah. Salah stau penjelasnnya adalah bahwa orang dengan gangguan kepribadian antisosal kemungkinan mengalami penurunan dalam hal pekerjaan, mungkin karena perilaku antisosial mereka membuat mereka sulit untuk memiliki pekerjaan tetap. Mungkin juga bahwa orang dari tingkat sosial ekonomi rendah lebih cenderung untuk diasuh oleh orang tua yang memberi panutan perilaku antisosial.

Ada hubungan kuat antara kriminalitas dan perilaku psikopat atau antisosial, namun tidak semua kriminalitas menunjukan gejala psikopat dan tidak semua psikopat berperilaku kriminalis (Lilienfeld \&
Andrews, 1996). Beberapa dari mereka taat hukum meski dari mereka mencirikan sebagai kejam serta tidak menghargai minat dan perasaan orang lain.

Para peneliti mulai memandang bahwa kepribadian psikopat terdiri dari dua dimensi yang agak terpisah. Yang pertama adalah dimensi kepribadian. Dimensi ini terdiri dari trait-trait seperti karisma yang tampak diluaran saja, mementingkan diri sendii, kurangnya empati, keji dan tidak ada penyesalan meski telah memanfaatkan orang lain, serta tidak menghargai perasaan dan kesejahteraan orang lain. Tipe kepribadian psikopat ini dikenakan pada orang yang memiliki trait psikopati namun tidak menjadi pelanggar hukum. Dimensi yang kedua dipertimbangkan adalah dimensi perkaku. Dimensi ini ditandai oleh gaya hidup yang tidak stabil dan antisosial, termasuk sering berhadapan dengan masalah hukum, riwayar pekerjaan yang minim, dan hubungan yang tidak stabil (Brown \& Forth, 1997; Cooke \& Michie, 1997). Kedua dimensi ini tidak sepenhnya terpisah; banyak individu psikopati menunjukan bukti memiliki kedua macam trait tersebut.

Untuk lebih rinci terkait dengan variasi kepribadian orang dengan antisosial, berikut ini dipaparkan Lima Variasi Kepribadian Antisosial yang dikemukakan oleh Millon \& Davis (2000), yaitu sebagai berikut: 
Lima Variasi Kepribadian Antisosial
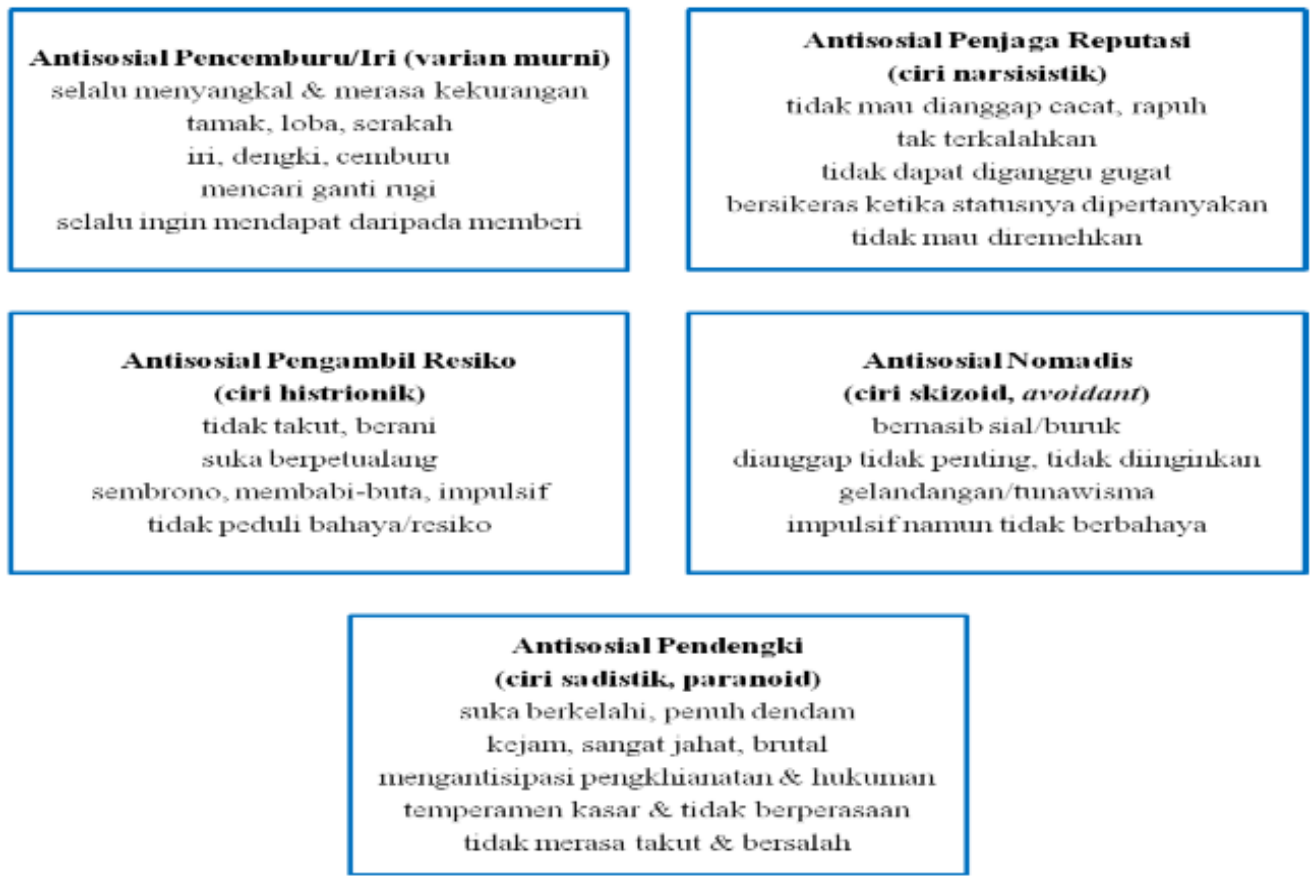

Sumber : Millon \& Davis 2000, 'The Antisocial Personality', in Personality Disorder in Modern Life, New

York : John Wiley \& Sons Inc., p. 102-36

Ciri-ciri Diagnostik dari gangguan kepribadian antisosial menurut Nevid, dkk (2005:279) yang diadaptasi dri DSM-IV-TR (APA, 2000) adalah sebagai berikut:

1) Paling tidak berusia 18 tahun

2) Ada bukri gangguan perilaku sebelum usia 15 tahun ditunjukan dengan pola perilaku seperti membolos, kabur, memulai perkelahian fisik, menggunakan senjata, memaksa seseorang untuk melakukan aktifitas seksual, kekejaman fisik pada orang atau binatang, merusak atau membakar bangunan secara sengaja, berbohong, mencuri, atau merampok.

3) Sejak usia 15 tahun menunjukan kepedulian yang kurang dan pelanggaran terhadap hak-hak orang lain, yang ditunjukan oleh beberapa perilaku sebagai berikut : a. Kurang patuh terhadap norma sisual dan peraturan hukum, ditunjukan dengan terlibat dalam perkelahuan fisik dan mengakibatkan penahanan, seperti merusak bangunan, terlibat dalam pekerjaan yang bertentangan dnegan hukum, mencuri, atau menganiyaya orang lain.

b. Agresif dan sangat mudah tersinggung saat berhubungan dengan orang lain, ditunjukan dengan terlibat dalam perkelahian fisik dan menyerang orang lain secara berulang, mungkin termasuk penganiyayaan terhadap pasangan atau anak-anak.

c. Secara konsisten tidak bertanggung jawab. 
d. Gagal membuat perencanaan masa depan atau impulsivitas, seperti ditunjukan oleh perilaku berjalan-jalan tanpa pekerjaan atau tujuan yang jelas.

e. Tidak menghormati kebenaran, ditunjukan dengan berulangkali berbohong, memberdaya, atau menggunakan orang lain untuk mencapai tujuan pribadi atau kesenangan.

f. Tidak menghargai keselamatan diri atau keselamatan orang lain, ditunjukan dengan berkedara saat mabuk atau berulangkali mengebut.

g. Kurangnya penyesalan atas kesalahan yang dibuat, ditunjukan dengan ketidakpedulian akan kesulitan yang ditimbulkan pada orang lain dan atau membuat alasan untuk kesulitas tersebut.

\section{METODE}

Artikel ini disusun dengan menggunakan kajian literatur dan dokumen, yaitu literatur barupa buku-buku, makalah ataupun jenis tulisan lainnya dan juga kajian terhadap berbagai macam dokumen yang terkait dengan topik gangguan kepribadian antisosial pada narapidana yang diangkat dalam artikel ini.

\section{PEMBAHASAN}

Kesehatan mental merupakan hal yang penting bagi manusia. Keadaan mental yang baik menggambarkan keadaan jiwa yang sehat. Namun, tidak jarang manusia tidak bisa menerima tekanan pada dirinya sehingga tidak jarang manusia terkena gangguan kesehatan mental. Gangguan mental atau penyakit mental menurut Semiun (2009: 9) merupakan penyakit yang menghalangi seseorang hidup sehat seperti yang diinginkan baik oleh diri individu itu sendiri maupun oleh orang lain. Berbagai gangguan mental diantaranya adalah gangguan mental ringan, kesulitan mengontrol emosional dari individu, dan juga gangguan mental yang berat. Gangguan mental mempunyai ragam yang banyak, salah satu dari sekian banyak gangguan mental tersebut adalah gangguan kepribadian yaitu biasa kitagunakan dengan kata psikopat atau sosiopat yang tidak lain adalah nama lain dari gangguan antisosial atau ASDP.

Sebutan 'Psikopat' dalam ilmu kesehatan mental diigunakan secara luas untuk orang yang mengalami gangguan kepribadian antisosial. Adapun gangguan kepribadian antisosial atau Antisocial Personality Disorder (ASDP) merupakan gangguan pada manusia dimana mereka yang terkena gangguan ini tidak dapat bekerjasama dengan baik dengan orang lain, kelompok, ataupun masyarakat. Beberapa buku, novel, film yang menggambarkan Individu dengan gangguan kepribadian Psikopat sudah tersebar di masyarakat, salah satunya adalah film yang di ambil dari novel yaitu The Silence of the Lambs dengan Dr. Lecter sebagai seorang psikopat atau pada film Gone Girl yang juga diadaptasi dari novel.

Pengidap gangguan psikopat, dalam beberapa gambaran, cenderung terlihat lebih cerdas dari individu-individu pada umumnya. Seseorang dengan gangguan psikopat atau antisosial ini cenderung susah untuk diketahui apakah ia mengidap gangguan psikopat atau tidak karena orang dengan gangguan penyakit kepribadian psikopat cenderung terlihat normal dan baik dalam masyarakat berbeda dengan pengidap gangguan Skizofrenia yang lebih tidak dapat bersatu dengan masyarakat dan berhalusinasi (Sumber bacaan: ruangpsikologi.com). Mereka kurang dapat mengontrol rasa empati mereka pada seseorang, mereka terkesan tidak perduli dengan perasaan orang-orang disekitar mereka dan mereka mencari kebenaran dari apa yang telah mereka lakukan meskipun itu tidak sesuai dengan 
niali-nilai yang ada. Beberapa dari mereka cenderung melakukan aktifitas kriminal seperti pelaku KDRT, pembunuhan, penganiyayan pada individu lain tanpa di ikuti dengan rasa bersalah setelah mereka melakukan tindakan tersebut. Karena hal-hal tersebut, maka seseorang dengan gangguan psikopat mempunyai hubungan dengan pelaku tindak kriminal dan mendekap dalam penjara.

Mari kita ulas contoh kasus salah satu tokoh psikopat. Adalah John Wayne Gacy merupakan seseorang dengan gangguan psikopat. Namun sebelum akhirnya mengetahui bahwa ia mengalami gangguan psikopat ia sempat dijatuhi hukuman 10 tahun karena dugaan melakukan melakukan pelecehan seksual berupa sodomi namun dia keluar setelah dua tahun tahanan karena perilaku baik dalam penjara. Namun, setelah dibebaskan dari penjara baru terusut bahwa ia menyimpan 26 mayat dan melakukan 25-30 kali pembunuhan kepada anak laki-laki. Kasus tersebut terbongkar setelah ia keluar dari penjara dan akibat dari kasus tersebut John difonis dengan hukuman mati.

Gangguan psikopat adalah salah satu bentuk dari gangguan mental, dengan kata lain, narapidana yang terdeteksi mengalami gangguan antisosial atau psikopat ini termasuk orang yang mempunyai penyakit mental dan mereka yang mengalami gangguan kejiwaan tentu membutuhkan perawatan medis dengan perlindungan sebagai pasien. Tetapi dilain sisi mereka merupakan seseorang yang perlu dihukum atau sanksi pidana karena tindakan kejahatan yang mereka lakukan dan bahkan menelan korban. Ini perlu menjadi sorotan berbagai pihak, khususnya orang-orang yang terlibat pada bagian hukum karena belum jelasnya undang-undang yg mengatur mengenai pelaku tindak kejahatan dengan gangguan kejiwaan. Disinilah peran dari pekerja sosial dibutuhkan dalam konteks koreksional. Pekerja sosial yang bekerja dengan narapidana harus dapat menelaah mengenai tahanan yang mempunyai gangguan psikopat dan bagaimana mereka mendapatkan hukumannya.

Sebagaimana adanya peraturan yang dikhususkan bagi tersangka tindak pidana yang terdeteksi mengalami gangguan mental pada dirinya dapat menghabiskan masa tahanan dalam rumah sakit mental untuk direhabilitasi agar mereka dapat sembuh dari penyakitnya tersebut. Ini sesuai dengan pernyataan pengadian Amerika pada buku Mental Health and Social Problem a Social Work Perspective (tahun dan halaman) bahwa:

Seorang narapidana penjara berhak untuk mendapatkan perawatan psikologis atau kejiwaan jika dokter atau penyedia perawatan kesehatan mental, keterampilan biasa dan peduli pada saat pengamatan, diakhiri dengan kepastian medis (1) bahwa gejala tahanan bukti penyakit serius atau cedera (2) bahwa penyakit atau cedera dapat diobati atau dapat dikurangi; dan (3) bahwa potensi bahaya pada tahanan dengan alasan keterlambatan atau penolakan perawatan akan besar.

Namun apakah narapidana dengan gangguan psikopat termasuk dalam kelompok narapidana yang membutuhkan perawatan medis dan terbebas dari hukuman. Jika dilihat secara menyeluruh, orang yang terkena gangguan psikopat dan melakukan tindak kriminal tidak menyadari akan kesalahan yang ia lakukan, ataupun menyadari namun tidak merasa bersalah sekalipun ia sudah melakukan tindak kriminal yang parah. Meskipun ia berhak pendapatkan terapi dan treatment dari para ahli, namun hukuman juga harus di berlakukan mengingat orang dengan gangguan psikopat yang melakukan tindak kriminalitas melakukan nya secara sadar. 
Dalam hal ini, pekerja sosial yang bekerja di ranah koreksional harus mengusut kasus bagaimana narapidana yang mempunyai masalah gangguan psikopat dapat mendapatkan haknya yaitu terapi atau pengobatan dan dapat berlaku adil. Namun sebelum itu harus dilakukan pengusutan tindak lanjut atas perbuatan mereka yang meresahkan tersebut apakah ia memang memiliki gangguan pada mental atau pun kepribadiannya atau mereka melakukan tindakan tersebut secara sadar. Untuk mengetahui apakah seseorang memiliki gangguan psikopat atau tidak, pekerja sosial harus bekerja sama dengan pihak medis dan juga psikolog melihat psikopat bukan seperti gangguan-gangguan mental yang lainnya melalui tes medis ataupun melawati analisis psikolog. Pekerja sosial pada ranah koreksional dapat bekerja sama dengan ahli lain untuk mendeteksi apakah ada diantara narapidana yang mempunyai gangguan psikopat atau tidak.

Pekerja sosial bersama psikolog dapat melakukan assessment kepada narapidana untuk nantinya mendeteksi kondisi intelektualitas tersangka tindak pidana, dalam rangka memperlancar proses penyidikan kepolisian atas tindakan yang dilakukan oleh tersangka tindak pidana tersebut. Pekerja sosial dan juga psikolog juga melakukan asesmen kondisi berisiko dan berbahaya dari tersangka, agar psikolog mendapatkan gambaran kemungkinan adanya kondisi berisiko dan berbahaya dari tersangka selama dalam proses penyidikan kepolisian. Ini penting dilakukan karena harus adanya pemeriksaan kepada setiap pelaku kriminal apakah ia mempunyai gangguan psikopat atau tidak agar rehabilitasi dapat dilakukan.

Adapun yang dapat dilakukan kepada penderita psikopat adalah terapi kognitif dan analisa secara menyeluruh terhadap lingkungan dan keluarga dari narapidana yang sudah positif mengidap gangguan psikopat perlu dilakukan untuk mengurangi obsesinya untuk melakukan tindakantindakan yang menyimpang dan mencegah kembali seorang dengan gangguan psikopat melakukan tindak kriminal

\section{SIMPULAN}

Narapidana merupakan pelaku tindak kriminal yang ditempatkan di dalam tahanan atau penjara karena kesalahan yang mereka lakukan. Beberapa narapidana dapat atau mungkin sudah terserang berbagai macam jenis gangguan mental akibat beberapa hal, salah satunya adalah gangguan psikopat.

Psikopat merupakan salah satu dari gangguan mental pada manusia. Gangguan psikopat pada manusia mempunyai keterkaitan dengan tindak kriminal, beberapa penderita gangguan psikopat merupakan pelaku tindak kriminal meskipun tidak semua pelaku tindak kriminal merupakan penderita gangguan psikopat. Adapun tersangka tindak pidana yang mempunyai gangguan psikopat dan mendekap didalam penjara tidak bisa menerima penangguhan hukuman mereka karena gangguan mental yang mereka miliki. Karena gangguan psikopat berbeda dari gangguan mental lainnya. Mereka sadar akan apa yang mereka lakukan namun mereka tidak merasa bersalah akan hal tersebut.

Pekerja sosial dalam ranah koreksional dapat membantu pihak berwajib untuk dapat mengetahui apakah seseorang narapidana mempunyai gangguan psikopat atau tidak pada dirinya untuk dapat membantu mereka menentukan hukuman apa yang di terima mereka dengan dan pekerja sosial dapat bekerja sama dengan pihak medis dan juga psikologi untuk mengetahui hal tersebut. Adapun yang dapat dilakukan pekerja sosial kepada narapidana yang sudah terdeteksi sebagai penderita psikopat adalah dengan memberikan terapi kognitif bersama dengan psikolog agar mereka dapat mengurangi tindakan kriminal mereka dan 
SHARE: SOCIAL WORK JURNAL
VOLUME: 7

NOMOR: 2
HALAMAN: 1 - 79

mengurangi tindakan kriminal yang mereka mungkin lakukan.

\section{DAFTAR PUSTAKA}

Barry, Patricia. 1998. Mental Health and Mental Illness Sixth Edition. New York : Lippincot.

Heller, Nina Rovinelli, Alex Gitterman. 2014. Mental Health and Social Problem a Social Work Perspective. Routledge

Millon \& Davis (2000), The Antisocial Personality, in Personality Disorder in Modern Life, New York: John Wiley \& Sons Inc., p.102-36

Nevid, Jeffrey; Spencer Rathus; Beverly Greene. 2005. Psikologi Abnormal edisi kelima jilid 1. Jakarta: Erlangga

Rudd, Betty. 2014. Introducing Psychopathology. London: SAGE

Semiun, Yustinus OFM. 2006. Kesehatan Mental 1. Yogyakarta: penerbit kanisius

http://hukum.unsrat.ac.id/

http://wikipedia.org/

http://www.bbc.com/

http://www.hukumonline.com/

http://www.ruangpsikologi.com/ 